\title{
The Intention To Become Police Officer
}

\author{
Nur Arifah Rahmah \\ Department of Psychology \\ Faculty of Medicine \\ Hasanuddin University \\ Makassar, Indonesia \\ arifahrahmah11@gmail.com
}

\author{
Muhammad Tamar \\ Department of Psychology \\ Faculty of Medicine \\ Hasanuddin University \\ Makassar, Indonesia \\ tamarpsikologiuh@gmail.com
}

\author{
Elvita Bellani \\ Department of Psychology \\ Faculty of Medicine \\ Hasanuddin University \\ Makassar, Indonesia \\ elvita.bellani@yahoo.com
}

\begin{abstract}
Police officer is expected to have a high integrity to do their job, so it is important to know their expectation, their motive, their belief and their objective. This research aims to examine intention to become police officer in youth and influencing factors by quantitative approach with correlation design. Numbers of participants in this research were 437 participants who were students of SPN Batua Police and Senior High School student grade 3 in Makassar. Questionnaires using Likert scale and opened question were distributed to participants. The technique of analyzing data was Spearman correlation test and content analysis as an additional analysis. The result shows significant positive correlation of attitude toward behavior, subjective norm, and perceived behavioral control to intention to become police officer. Intention to become police officer also differentiate by several background factors such as age, gender, culture, and parents background include education, occupation, and income.
\end{abstract}

Keywords-Police Officer; Theory of Planned Behavior; Intention

\section{INTRODUCTION}

Police department is an organization with goals to achieve, and human resources of the organization is one of the component to achieve these goals. Wexley and Yulk [1] propose that person (human resources) is one of the components in organization, which can support the achievement of organization goals.

Police officers are expected to behave with integrity. However, there are public's negative views of police officers, that raise questions about the quality of police officers. This can be seen from the number of violations of the law committed by the police officers themselves [2]-[5]. Various violations of law show that police officers disregard their role as law enforcer.

Police officer candidates will be the future of police department. Their intentions as seen in their expectations, motives, beliefs, and objectives will determined their quality of conduct. Therefore, this research aims to investigate police officer candidates' intention to become police officer.

\section{LITERATURE REVIEW}

\section{A. Intention}

According to theory of planned behavior, intention is assumed to be predictor of behavior. Intention captures motivational factors also how strong a person willingness to perform the intended behavior. [6] [7]

There are studies aim to examine predictive ability of intention to behavior. These studies propose that intention can serve as significant predictor of behavior in many context, for example, health related behavior [8], and occupational choice [9]. However, correlation between intention and behavior is differ across the domain of behavior examined. Overall mean correlation from meta-analysis shows 0.53 [10] and 0.47. [11] Arguably, this prediction power is reduced when there is a longtime interval between intention and behavior, also when people have no control over the intended behavior [6].

\section{B. Basic Factors Determining Intention and its Antecedents}

Azjen [6] propose that Theory of Planned Behavior does not only predict, but also explain behavior. Intention analysis provide background and antecedent information regarding the intended behavior. Accordingly, Azjen argues that behavior occurs as a function of belief related to intended behavior. These consist of behavioral belief, normative belief, and control belief. These beliefs are determinant of intention and thus can serve as background information of behavior [6][7][10][11].

- Attitude Toward Behavior

Attitude toward the behavior refers to what extend a behavior can result in positive or negative outcomes. This factor is determined by behavioral belief about consequences result in performing certain behavior, also a person's evaluation regarding whether the positive or negative outcome is desirable or undesirable.

- Subjective Norm

Subjective norm refers to a person perception about social pressure regarding whether to perform or not to carry out certain behavior. This social pressure creates a normative belief, which is belief about social referent (e.g. parents, partner, friends, expert) agreement or disagreement regarding certain behavior. To generate subjective norm, normative belief should be accompanied by motivation to comply, which is a person motivation to comply with social referent expectation.

- Perceived Behavioral Control

Perceived behavioral control refers to a person perception about an ease or difficulty to perform certain action. Perceived behavioral control is determined by the 
combination of control belief and perceived power control. Control belief refers to belief regarding supporting and inhibiting factors to perform certain behavior. Control belief is obtained from experience, or form other experience regarding experience of performing certain action. Perceived power control refers to perceived power regarding facilitating or inhibiting factors in performing such behavior.

\section{METHOD}

\section{A. Participants}

There were 437 participants which consists SPN Batua students and $3^{\text {rd }}$ grade Senior High School students. SPN Batua is police academy where high school graduate students are educated for 7 months to become police officer. All participants age 17-21 years and were selected using block random sampling.

\section{B. Procedures}

Questionnaires were distributed in participants' class. Firstly, investigator distributed the questionnaires, and then invited participants to read informed consent. Should they agree, they were asked to sign the approval of participation in research. After that, participants were asked to fill out questionnaires: the Likert scale and then to answer the openended questions.

\section{Measures}

The measures were questionnaire developed by investigator from Ajzen intention scale sample [7]. The questionnaire using Likert scale. Additionally, there were open-ended question to further analyze the data.

This scale consists of 70 items, including four variables to be measured, i.e. intention, attitude toward the behavior, subjective norm, and perceived behavior control. The validity test done by validity construct test by using CFA (Confirmatory Factor Analysis). The reliability test of Croncbach's Alpha is 0.955 .

\section{Data Analysis}

Data analysis were consisted of quantitative and qualitative analysis. Firstly, for quantitative analysis, +/- 1.5 SD equation were employed to categorize data into three categories: Low, moderate, high. Data below -1.5 SD were categorized as low, between $-1.5 \mathrm{SD}$ and 1.5 SD were categorized as moderate and data above 1.5 SD were categorized as high. To analyze correlation, Rank Spearman Correlation were employed and for qualitative data analysis, content analysis was used.

\section{RESUlT}

The result shows intention to become police officer is majority in high category $(55 \%)$. There is positive correlation of attitude toward behavior $\mathrm{r}_{\mathrm{s}}=0,849, p<.05$, subjective norm, $\mathrm{r}_{\mathrm{s}}=0,391 p<.05$ and perceived behavioral control, $\mathrm{r}_{\mathrm{s}}=0,872$, $p<.05$. Qualitative data analysis shows that attitude toward behavior to evaluate the benefits of being a police officer, are: to elevate the social status of the family; to have uniforms to work; and to earn a lot of money form parking ticket. While negative outcomes are; reduce time with family, risky jobs, and limited freedom. The explanation of perceive behavior control for factors that support to become a police officer are: desire to follow in the footstep of parents who are also a police officer; ability to improve family economy; and motivation to serve the nation and the state; The perceived inhibiting factor is the high number of competitors to become police and economic barriers associated with the cost of becoming a police officer.

Intention to become police officer are also differed across demography factors namely age, gender, culture, and parents background include education, occupation, and income. Men have a higher intention to become police officer. Based on the background of parents on the type of work, the farmer shows the highest intention of becoming a police officer among other occupations. Related to parents' education, primary school graduates have a highest intention to become police officer, and related to income, lowest income category (less than IDR 2 million or equal to U\$ 147.8 per month) has the highest intention to become a police officer.

\section{DISCUSSION}

This present study aims to examine intention to become police officer in youth. This result is important as it will predict and explain intention to become police officer in youth who will be the future of police officer. Result of this study shows that majority $(55 \%)$ of participants have high intention to become police officer. This present study also shows that there are significant positive correlations between prediction factors and intention; attitude toward behavior $\left(r_{s=0.849,} p<.05\right)$, subjective norm $\left(r_{s}=0.391, p<.05\right)$ dan perceived behavioral control $\left(r_{s}=0.872, p<.05\right)$.

Ajzen [7] proposes that there are three predictors of intention. However, not all predictors should share the same contribution to predict intention. It really depends on what intention to be analyzed. The result of this study shows that the strongest correlation is shown by perceived behavioral control which is $\left(r_{s}=0.872, p<.05\right)$. Accordingly, when participants perceived there is an ease to become police officer, they are likely to have a high intention to become police officer. A possible explanation for this result may be caused by direct causal relationship between perceived behavioral control and intention. Moreover, perceived behavioral control can directly influenced behavior because it is considered as partial substitution of the real control.

Qualitative data gathered from this result provide explanation of facilitating factors to become police officer. Perceive of ease to become police officer are: strong willingness to have the same occupation with their parents; economic factors; and motivation to serve the country. This control belief along to what extend the person have power to control the facilitating factors (i.e. perceived power control) can serve as motivational drive to become a police officer. 
The second strongest correlation is shown from correlation between attitude toward behavior and intention $r s .849, \mathrm{p}<.05$. This result shows that when participants perceive there are great numbers of benefit to become police officer, they are likely to have high intention to become police officer. This behavioral belief is followed by the outcome evaluation which shows that participants perceive the positive outcomes expected are likely to happen

The results of open questions show that the positive outcome expected by becoming a police officer is related to motivation to raise their and their family social status. Most participants with high intentions to become police officer came from parents with low incomes, elementary school graduates and have a job as farmers. In other words, they came from a low socioeconomic group [12]. In addition to predicting behavior, the Theory of Planned Behavior is also serve to explain one's motivation [7]. The result as of this study shows that the motivation to be a police officer is driven by behavioral belief that a job as a police officer is a job can raise social status. This indicates that the motivation to be police is driven by the esteem needs, which is need for recognition of others [13]. In other words, the motivation to be a police officer, especially from participants who come from low social economy is driven by the need for acknowledgment from others.

Furthermore, motivation has correlation with job performance [14]. In line with research by Larasati and Gilang, work motivation is stimulatingly and partially influence work performance [15]. Accordingly, a person motivation to become police officer will influence his/her performance as police officer. This result shows that most of participants, especially from low social status evaluate a job as police officer will provide positive outcomes, such as improving social status, proud of police uniform, grow maturity, and interestingly, receive a lot of money from parking ticket. In addition to esteem needs as describe above, examining intention to become police officer also provide information about what people expect to achieve and describe their goals to become police officer, which will influence their performance as police officer.

The next predictor is subjective norm, which has a positive correlation with intention to become police officer, $r_{s} 0,391, p$ $<.05$. The correlation coefficient shows that this factor has the lowest correlation when compared to the other two factors. This suggests that the subjects has a normative belief that their social referents (those closest to the subject, such as parents, close friends, spouses, and other important people involved in performing behaviors) expect them to become a police officer. This expectation creates social pressure to become police officers. However, this normative beliefs is not followed by motivation to comply. As a consequence, although normative beliefs are quite high, subjective norms only weakly associated with intentions. One possible explanation for this result is that most participants are in late adolescent. According to Santrock, late adolescent go through rapid development on physical, cognitive, social and emotional [16] [17]. These rapid developments are followed by various changes, both physical, cognitive, social and emotional. As their developed, adolescents are no longer dependent to the opinion of their social referent when it comes to make a decision. In this case, mostly late adolescent realize that decision regarding what to do after high school is his/her responsibility. Arguably, although there is social pressure from social referent to become police officer, participants do not automatically follow their social referent opinion. As consequences, correlation between subjective norms and intention is weak.

This present study reveals various reasons, backgrounds, motives, and views about police officers. In fact, negative and misconception about being a police officer (e.g. parking ticket, takes a lot of money to become a police officer) also revealed. According to Azjen [6] intention not only predict behavior but also explain behavior as it provide explanation about belief that drive the behavior. As there are a lot of misconception about police officer, it is important that police officers socialize objective description about police officer to correct the fallacy held by society. We suggest that this can be deliver by encouraging integrity in performing duty as police officer also by organizing socialization about police officer and police department, especially to those who has indentation to become police officer.

\section{LIMITATION}

We aware that our research may have limitations which result in restricted generalization of the result. There is only small number of participants which result in under representation of population. The result of this study does not follow Gaugasion distribution. After dividing data with 1.5 SD, data become extremely categorized. There are $55 \%$ of data are categorized as high intention, $8 \%$ of data are categorized as moderate intention, and $10 \%$ of data are categorized as low intention. We suggest that to obtain more objective picture about intention to become police officer, future study should be conducted involving more participants.

\section{CONCLUSION}

The present study shows that almost all participants $(55 \%)$ have high intention to become police officer, followed by $8 \%$ with moderate intention and $10 \%$ with low intention. Three factors determining intention are significantly correlated with intention: (1) attitude toward the behavior ( $\left.r_{s} .849\right)$; (2) subjective norm $\left(r_{s} 0,391\right)$; and (3) perceived behavioral control $\left(r_{s} .872\right)$. This study also reveals that intention to become a police officer are also differs across demography factors, namely, age, gender, culture and parents' education, parents' job and parents' income. Based on open ended questionnaire, most of the participants are driven by belief that police officer is respectable job and being a police officer will increase their social class. However, there are some of the misconception held by participants about police officer that we are strongly suggest to fix by police department. 


\section{REFERENCES}

[1] K.N. Wexley and A.G. Yulk. Organizational Behavior and Personnel Psychology. USA: Richard D.Irwin 1997.

[2] K Efrata. Politik. Re : Polisi Bali yang Disuap di Youtube Kini Dipenjara.Internet:http://www.tempo.co/read/news/2013/04/17/0634 74098/Polisi-Bali-yang-Disuap-di-Youtube-Kini-Dipenjara. [Aug 2 2017]

[3] Saputra. "Ada 17 Kasus yang Dilakukan Anggota Polisi di Awal 2013."

Internet: http://news.okezone.com/read/2013/04/02/337/784713/ada-17kasus-yang-dilakukan-anggota-polisi-di-awal-2013, [Aug 1 2017]

[4] A. Sasongko. "Ini Data Pelanggaran yang Dilakukan Anggota Polri." Internet:

http://nasional.republika.co.id/berita/nasional/hukum/14/12/09/ngbie w-ini-data-pelanggaran-yang-dilakukan-anggota-polri [Aug 1 2017]

[5] Y. Yusuf. "Penyidik Telusuri Korban Lain Oknum Polisi Perampok." Internet: https://metro.sindonews.com/read/1060437/170/penyidik-telusurikorban-lain-oknum-polisi-perampok-1447155208 [Aug 5 2017]

[6] I. Ajzen. "The Theory of Planned Behavior", Organizational Behaviour and Human Decision Process, vol. 50, pp 179-211, 2011

[7] I. Azjen. Attitude, Personalitiy, and Behavior, $2^{\text {nd }}$ Ed, Milton-Keynes, England: Open University Press/McGraw- Hill, 2005.

[8] G. Godin and G. Kok. "The Theory of Planned Behavior: a review of its application to health-related behaviors." American Journal of Health Promotion, vol. 11, pp 87-98, 1996

[9] T. Kautonen, M. Van Gelderen, and E.T. Tornikoski. "Predicting Entrepreneurial Behavior: a test of the theory of planned behavior: Applied Economics, vol. 45, pp. 697-707, 2013

[10] I. Ajzen. "The Theory of Planned Behavior" In P. A. M. Lange, A. W. Kruglanski \& E. T. Higgins (Eds.), Handbook of theories of social psychology, vol. 1, London, UK: Sage, 2012, pp. 438-459,.

[11] I. Ajzen, I and Fishbein, M., The influence of attitudes on behavior. In D. Albarracín, B. T. Johnson, \& M. P. Zanna (Eds.), The handbook of attitudes, pp. 173-221. Mahwah, NJ: Erlbaum, 2005.

[12] K. Maryati, K and J. Suryawati. Sosisologi For SMA dan MA. Jakarta: Erlangga, 2001.

[13] Alwisol, Psikologi Kepribadian. Malang: UMM Press, 2012.

[14] R.E. Riggio. "Introduction to Industrial/Organizational Psychology, $5^{\text {th }}$ ed" America : Pearson International Edition, 2009.

[15] S. Larasati and A. Gilang. "Pengaruh Motivasi Kerja terhadap Kinerja Karyawan Wilayah Telkom Jabar Barat Utara (Witel Bekasi)". Journal of Management and Organization, Indonesia, vol. 5, pp 200213, 2014.

[16] E. Hurlock. Psikologi Perkembangan. Jakarta: Erlangga, 2002.

[17] J.W.Santrok. Life Span Development. Jilid 1, $13^{\text {rd }}$ ed, Jakarta: Erlangga, 2012 